\title{
Effect of differently managed legumes on the early development of oil palms (Elaeis guineensis Jacq.)
}

\begin{abstract}
We studied the effects of different covers (none, legume and natural) established in different ways (with legumes only: hand-weeded, hand-weeded plus extra fertilizer, and with preemergent application of the herbicide Oxyfluorfen at $0.25 \mathrm{~kg}$ active ingredient hai 1), on the first 3.5 years' growth and yield of oil palms (Elaeis guineensis Jacq). Legumes were a mixture of Centrosema pubescens and Pueraria phaseoloides. Natural generation consisted mostly of Nephrolepis biserrata and Paspalum conjugatum. Early rates of growth of the palms (as measured by frond area, girth, height, etc.) were greatest in the bare plots and the first yields of fresh fruit bunches were significantly higher than with any other treatment. On the other hand, relative growth rates and net assimilation rates were higher in legume plots (particularly those established with Oxyfluorfen) throughout most of the experimental period. This means that the rate of growth of palms in legume treated plots steadily overtook the rate of growth of those in bare plots. Presumably, these differences resulted from rapid exploitation of soil nutrients by palms in bare plots, and the ñbankingò of these same nutrients in legume plots.
\end{abstract}

Keyword: Legumes; Oil palms 